\section{Mapping Grassland Management Intensity Using Sentinel-2 Satellite Data}

Gl_Forum 2018, Issue 1

Page: 194 - 213

Full Paper

Corresponding Author:

m_e_bekkema@hotmail.com

DOI: 10.1553/giscience2018_01_s194

\author{
Marijke Elisabeth Bekkema ${ }^{1}$ and Marieke Eleveld 1,2 \\ IUNIGIS, Vrije Universiteit Amsterdam, The Netherlands \\ 2Deltares, Delft, The Netherlands
}

\begin{abstract}
For the conservation of biodiversity in general and the monitoring of meadow birds in particular, actual grassland-use intensity maps are highly desirable. A method to map and assess grassland management intensity was developed using C5.0 decision tree classification on Sentinel-2 satellite data. Monoculture and extensively managed grasslands on both peat and clay soils could be accurately detected at parcel level in Friesland, the Netherlands. Field-survey-based validation returned an overall classification accuracy of $84.3 \%$ (KHAT 0.65). The Sentinel-2 Red-Edge Position vegetation index was found to be a good indicator of fertilization. Availability of springtime imagery, preferably acquired in April before the first mowing date, is essential for accurate classification. The spectral responses of grassland types on peat and clay soils differ significantly. Hence, successful classification requires training data for both soil types. The resulting grassland management map was used to assess the distribution of meadow bird nests. Redshank $(79 \%)$ and godwit $(77 \%)$ in particular choose to breed on extensive parcels. With the increasing availability of satellite imagery, remote sensing techniques can be used to monitor agri-environmental measures (at parcel and landscape scale) that impact the conservation of grassland biodiversity.
\end{abstract}

\title{
Keywords:
}

Earth observation, Sentinel-2, biodiversity, grassland management, meadow bird habitat mapping

\section{Introduction}

Actual grassland-use intensity maps are highly desirable for the study and conservation of biodiversity and the monitoring of meadow birds (Howison, Piersma, Kentie, Hooijmeijer \& Olff, 2018). Agricultural intensification of grassland use is one of the main causes of meadow bird decline. This has been evidenced for example in Friesland, the Netherlands (Groen et al., 2012; Kentie, Hooijmeijer, Trimbos, Groen \& Piersma, 2013). Extensively managed herb-rich grassland forms the traditional meadow bird habitat, but it has become rare (Figure 1). By extensive management is meant: no application of artificial fertilizer or liquid manure, limited grazing, first mowing date after 15 June, and preservation of high groundwater levels. 
Nowadays, most farmers have moved to intensively managed ryegrass (Lolium perenne) monocultures. In these grasslands, juvenile meadow birds have little chance to survive due to frequent mowing (ca. once a month from April to October) and lack of high-quality food (Kentie et al., 2013).

Ground-based methods for grassland surveying and monitoring are time-consuming and expensive due to the large surface areas and spatio-temporal variability of grassland-use intensity. This is why Remote Sensing (RS) techniques have been used increasingly in grassland research (Ali, Cawkwell, Dwyer, Barrett \& Green, 2016). However, research that uses RS for assessing agricultural grassland management intensity at parcel level is still rare (Asam, Klein \& Dech, 2015; Courault et al., 2010; Dussaux, Vertès, Corpetti, Corgne \& Hubert-Moy, 2014; Franke, Keuck \& Siegert, 2012; Sibanda, Mutanga \& Rouget, 2017). Current availability of imagery with high spatio-temporal resolution offers new perspectives for this type of research (Asam et al., 2015).
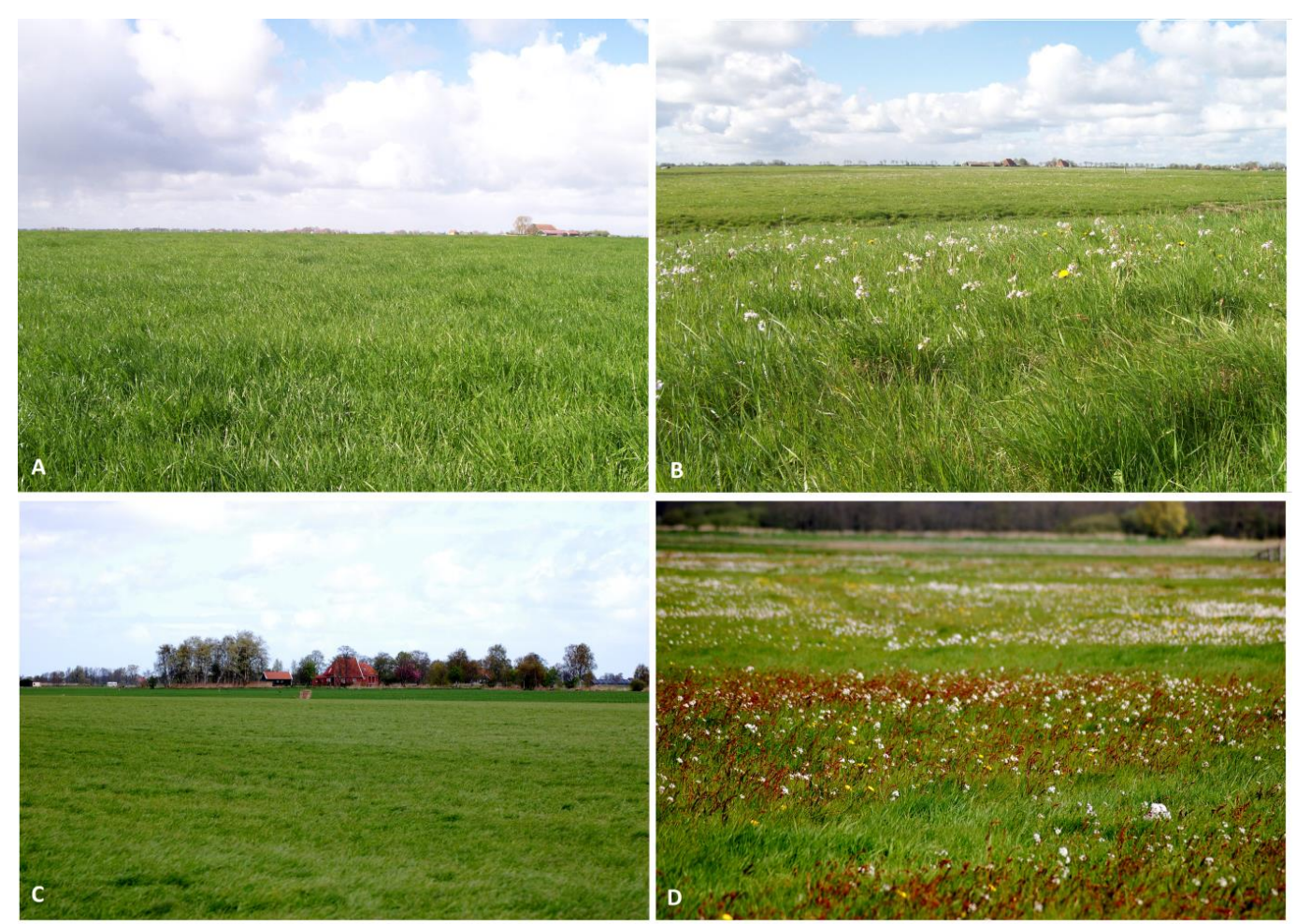

Figure 1: Differences between extensive and monoculture grassland on clay and peat soils (April 2017).

A: Monoculture grassland, clay soil area (17 April 2017);

B: Extensive grassland, clay soil area (17 April 2017);

C: Monoculture grassland, peat soil area (22 April 2017);

D: Extensive grassland, peat soil area (22 April 2017). 
Because grasslands display a very similar spectral signature, information from specific wavelengths is required to discriminate between different grassland types (Ali et al., 2016). Several satellites, e.g. RapidEye, WorldView-3 and Sentinel-2, now collect data in the rededge wavelengths. Healthy green vegetation has a characteristic spectral response, with a steep increase between maximum absorption of red light and maximum reflectance of near infrared light (Figure 2). The steepest point of this 'red-edge' is called the red-edge position (REP). The REP varies depending on vegetation type and is related to vegetation chlorophyll content (Clevers \& Gitelson, 2013; Frampton, Dash, Watmough \& Milton, 2013). It is also suitable for estimating leaf nitrogen content (Clevers \& Gitelson, 2013; Ramoelo, Cho, Mathieu \& Skidmore, 2015). Using red-edge bands in vegetation indices reduces the saturation effect which is often found in the NDVI (Normalized Difference Vegetation Index), because in the red-edge region, absorption by chlorophyll is lower than in the red visible light region (Clevers \& Gitelson, 2013). An increase in leaf chlorophyll content causes a shift in the REP towards longer wavelengths (Delegido et al., 2013). This shift has also been found for grasslands treated with fertilizer (Sibanda, Mutanga \& Rouget, 2015; Sibanda et al., 2017). REP values near $700 \mathrm{~nm}$ have been associated with low leaf chlorophyll concentration, whilst values near $725 \mathrm{~nm}$ point to high leaf chlorophyll concentration (Cho \& Skidmore, 2006). Several studies have shown that the inclusion of data from the red-edge part of the spectrum can improve grassland-use classification results (Franke et al., 2012; Schuster, Förster \& Kleinschmit, 2012; Sibanda et al., 2017). This paper (i) explores the potential of Sentinel-2 satellite data for detecting grassland management intensity at parcel level in a study area in Friesland, the Netherlands; (ii) compares classification parameter values for peat and clay soils; (iii) compares grassland management intensity to the distribution of meadow bird nest sites.

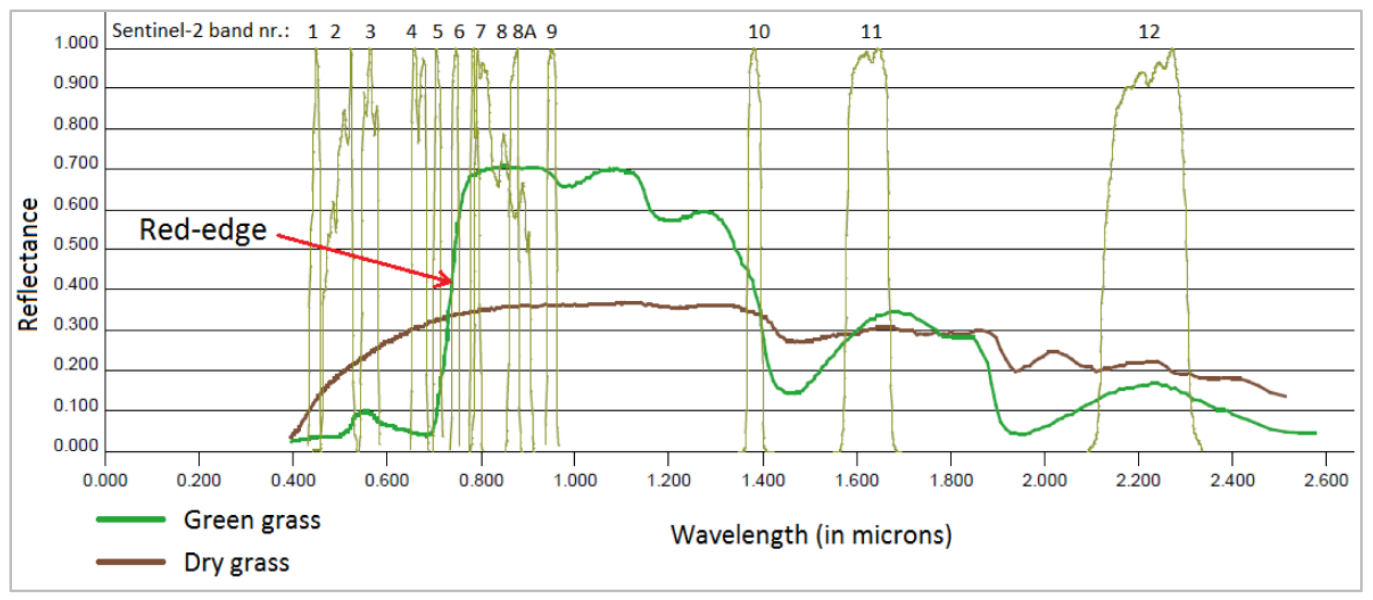

Figure 2: Spectral response curves of dry grass and lawn grass vs. distribution of Sentinel-2 spectral bands (modified from USGS 2017); details on S-2 bands in: https://earth.esa.int/web/sentinel/technicalguides/sentinel-2-msi/performance) 


\section{Methods}

The methods build on the research of Franke et al. (2012), who successfully mapped grassland management intensity at parcel level in southern Germany. They used RapidEye imagery for five observation dates and based their classification on See5 derived rulesets, using thresholds for the Normalized Red-Edge Vegetation Index (NREVI), NDVI, and their Mean Absolute Spectral Dynamic (MASD) indicator for spectral variability, which were implemented in eCognition. The current research uses only freely available data and opensource tools. Analyses are based on Sentinel-2 data for nine observation dates. The Sentinel2 Red-Edge Position (S2REP) replaces the NREVI (Figure 3). Differences in parameter values for peat and clay soils are also assessed.

\section{Remote Sensing of grassland management}

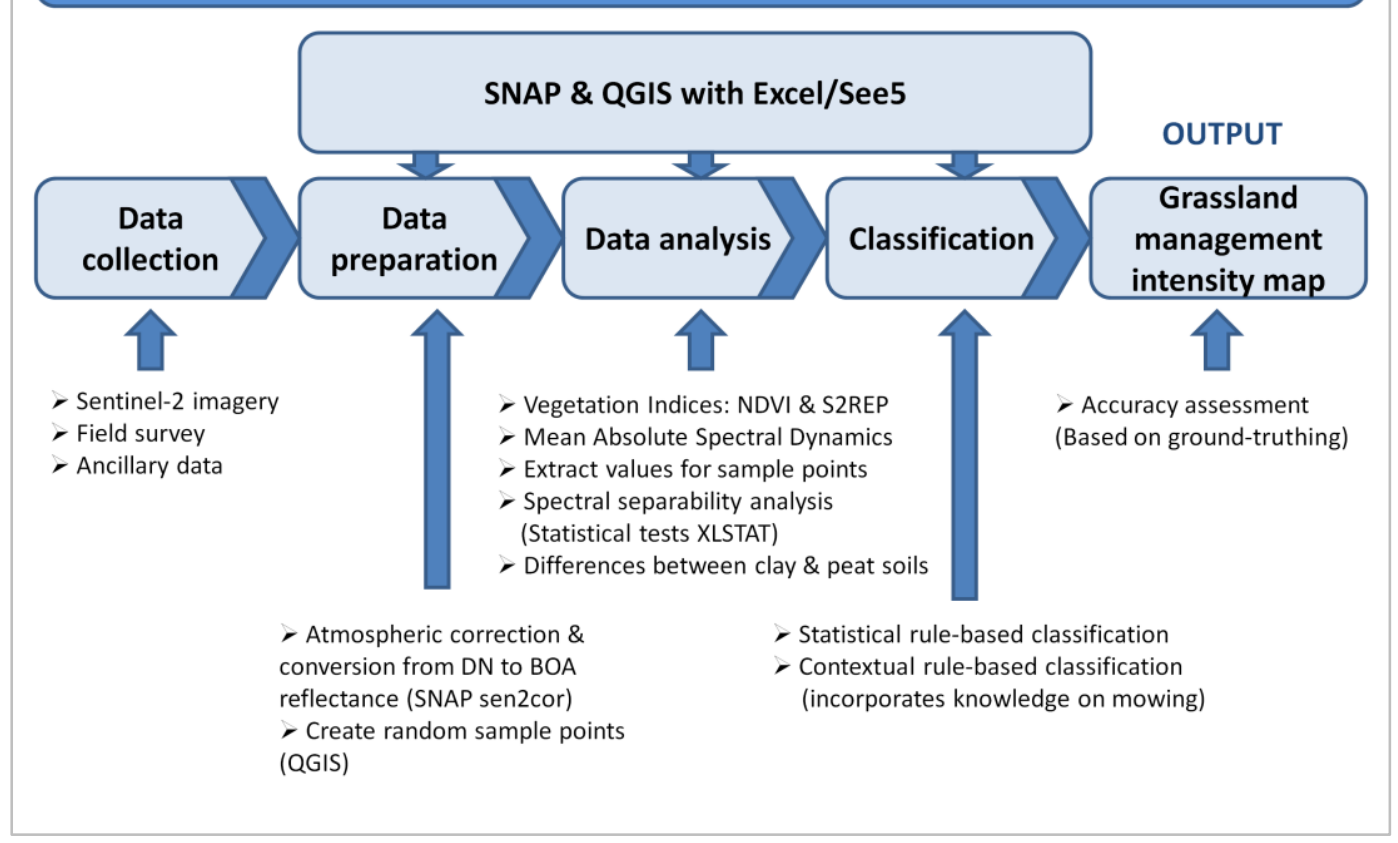

Figure 3: Method workflow

\section{Study area and field surveys}

The study area comprises South-Central Friesland $\left(1610 \mathrm{~km}^{2}\right)$, in the north of the Netherlands (Figure 4). This area has a history of meadow bird research (Groen et al., 2012; Kentie et al., 2013). Land cover is dominated by grassland, used for sheep and dairy cattle farming. Elevation varies between $-3.0 \mathrm{~m}$ to $12.7 \mathrm{~m}$ AMSL. To study the influence of soil 
type on spectral reflectance values, two field survey areas were chosen: the municipality of Littenseradiel $\left(132 \mathrm{~km}^{2}\right)$, representing an area with clay soils, and Grouw $\left(102 \mathrm{~km}^{2}\right)$, an area dominated by peat soils. Littenseradiel includes the meadow bird reserves Skrok, Skrins and Lionserpolder. The Grouw area includes part of the De Alde Feanen National Park, a Natura 2000 site with several important meadow bird areas, e.g. De Burd and Wyldlannen. In October 2016, sample areas representing monoculture grassland were selected through field survey. Bird reserves, derived from maps of nature management plans (Provincie Fryslân, 2017), were used as sample areas for extensive grassland. Parcel geometry for grasslands was extracted from the 2016 cropland registration dataset (Nationaal georegister, 2017). The field survey was repeated for the whole of Littenseradiel in the second half of April 2017, when the visible differences in grassland management intensity are most pronounced, thanks to the presence of flowering herbs. A vector map showing the grassland type for each parcel was created and used for accuracy assessment.

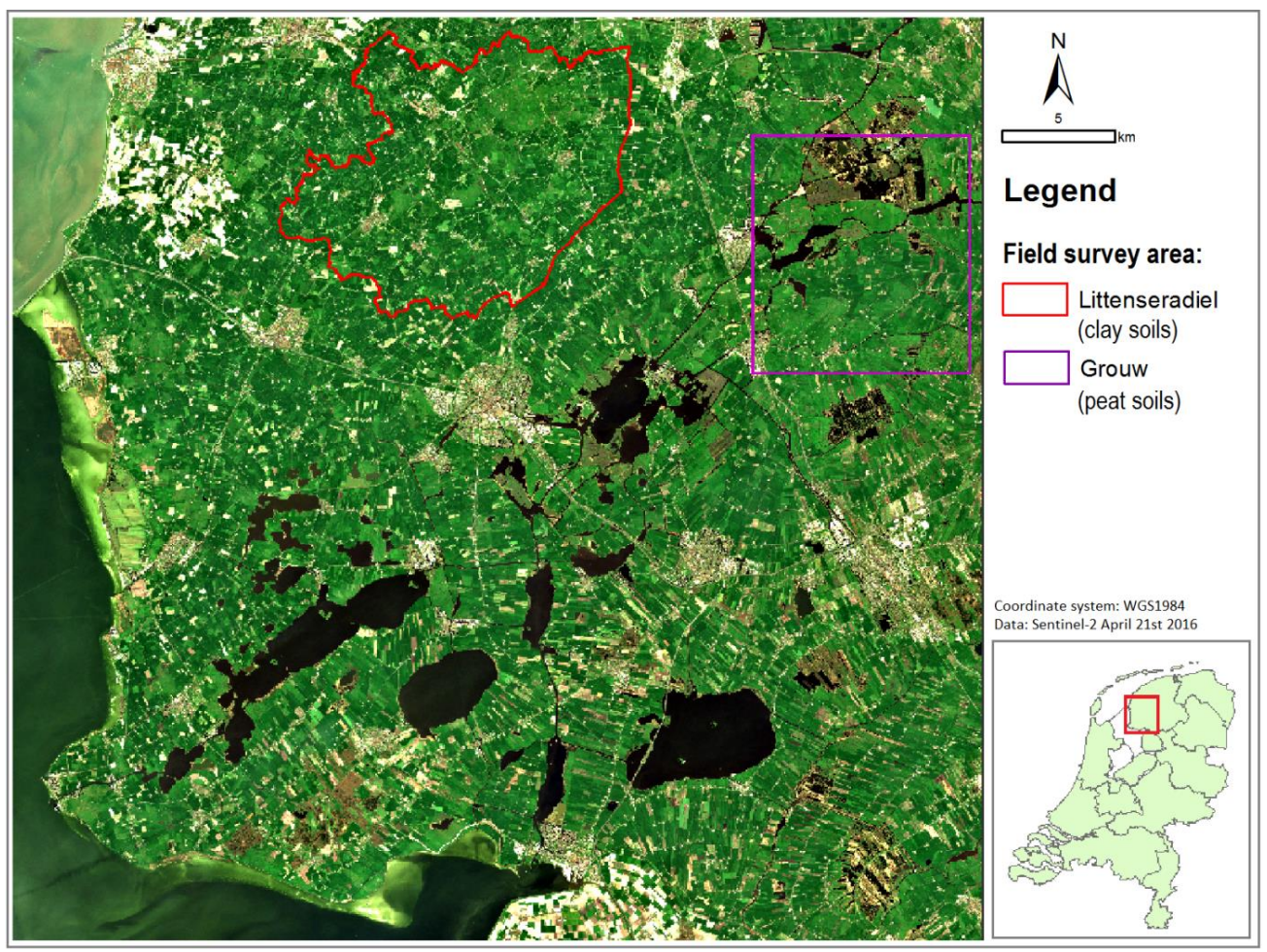

Figure 4: True colour composite (B4-B3-B2) of Sentinel-2 image of the study area (21 April 2016)

\section{Data and pre-processing}

The Sentinel-2 mission, part of the European Copernicus programme, makes provision for two identical polar-orbiting satellites in sun-synchronous orbit, phased opposite to each other at an altitude of $786 \mathrm{~km}$. Their revisit time is five days at the equator. Sentinel-2A was launched on 23 June 2015 and Sentinel-2B on 7 March 2017 (ESA, 2017a). Data is collected 
for 13 spectral bands at 10, 20 or $60 \mathrm{~m}$ spatial resolution (Figure 2). For the study area, nine Sentinel-2A datasets with little to no cloud cover were available for the 2016 growing season (Table 1). These Level-1C datasets, consisting of radiometrically corrected, orthorectified products in the UTM-WGS84 projected coordinate system, were downloaded using ESA's Scientific Data Hub (ESA, 2017b). Atmospherically corrected Level-2A bottom-ofatmosphere reflectance products were generated using the Sen2Cor (v2.3.0) Level-2A processor implemented in the Sentinel Application Platform (SNAP 5.0), at $10 \mathrm{~m}$ resolution (Mueller-Wilm, 2016). Smoothing of NDVI and S2REP time series, for example by using filtering methods, was not applied because of the risk of losing small fluctuations which might represent grazing or mowing (Halabuk, Mojses, Halabuk \& David, 2015).

Table 1: Overview of Sentinel-2 datasets used for the 2016 growing season. Values for solar zenith and viewing geometry (Mean view zenith angle and Sun zenith angle) were taken from the pixel that represents Itens, Littenseradiel

\begin{tabular}{|l|l|l|l|l|}
\hline Granules & $\begin{array}{l}\text { Acquisiti } \\
\text { on Date }\end{array}$ & $\begin{array}{l}\text { Mean } \\
\text { view }\end{array}$ & $\begin{array}{l}\text { Sun } \\
\text { zenith }\end{array}$ & $\begin{array}{l}\text { Cloud } \\
\text { y }\end{array}$ \\
\hline $\begin{array}{l}\text { S2A_OPER_MSI_L1C_TL_SGS_20160 } \\
\text { 312T181201_A003766_T31UFU_N02.01 }\end{array}$ & $\begin{array}{l}12 \text { March } \\
10: 50: 37\end{array}$ & $3.48^{\circ}$ & $57.20^{\circ}$ & 0.0104 \\
\hline $\begin{array}{l}\text { S2A_OPER_MSI_L1C_TL_SGS_20160 } \\
\text { 401T163301_A004052_T31UFU_N02.01 }\end{array}$ & $\begin{array}{l}1 \text { April } \\
10: 50: 24\end{array}$ & $3.46^{\circ}$ & $49.21^{\circ}$ & $\begin{array}{l}22.647 \\
5\end{array}$ \\
\hline $\begin{array}{l}\text { S2A_OPER_MSI_L1C_TL_SGS_20160 } \\
\text { 411T150737_A004195_T31UFU_N02.01 }\end{array}$ & $\begin{array}{l}11 \text { April } \\
10: 50: 25\end{array}$ & $3.47^{\circ}$ & $45.38^{\circ}$ & 0 \\
\hline $\begin{array}{l}\text { S2A_OPER_MSI_L1C_TL_MPS_20160 } \\
\text { 421T130055_A004338_T31UFU_N02.01 }\end{array}$ & $\begin{array}{l}21 \text { April } \\
10: 50: 29\end{array}$ & $3.51^{\circ}$ & $41.81^{\circ}$ & 0.8841 \\
\hline $\begin{array}{l}\text { S2A_OPER_MSI_L1C_TL_SGS_20160 } \\
\text { 508T163213_A004581_T31UFU_N02.02 }\end{array}$ & $\begin{array}{l}8 \text { May } \\
10: 40: 27\end{array}$ & $9.77^{\circ}$ & $37.05^{\circ}$ & 0.0032 \\
\hline $\begin{array}{l}\text { S2A_OPER_MSI_L1C_TL_SGS_20160 } \\
\text { 607T162830_A005010_T31UFU_N02.02 }\end{array}$ & $\begin{array}{l}7 \text { June } \\
10: 40: 26\end{array}$ & $9.80^{\circ}$ & $31.78^{\circ}$ & 10.311 \\
\hline $\begin{array}{l}\text { S2A_OPER_MSI_L1C_TL_MTI_20160 } \\
\text { 727T121350_A005625_T31UFU_N02.04 }\end{array}$ & $\begin{array}{l}20 \text { July } \\
10: 55: 47\end{array}$ & $3.54^{\circ}$ & $33.87^{\circ}$ & 0 \\
\hline $\begin{array}{l}\text { S2A_OPER_MSI_L1C_TL_SGS_20160 } \\
\text { 908T161324_A006340_T31UFU_N02.04 }\end{array}$ & $\begin{array}{l}8 \text { Sept. } \\
10: 54: 16\end{array}$ & $3.56^{\circ}$ & $48.36^{\circ}$ & 0 \\
\hline $\begin{array}{l}\text { S2A_OPER_MSI_L1C_TL_SGS_20160 } \\
\text { 925T161027_A006583_T31UFU_N02.04 }\end{array}$ & $\begin{array}{l}25 \mathrm{Sept.} \\
10: 41: 15\end{array}$ & $9.88^{\circ}$ & $54.98^{\circ}$ & 0 \\
\hline
\end{tabular}

\section{Mapping}

\section{Sample points}

Using QGIS v2.18.1, 400 random sample points were created within the polygons of extensive and monoculture grassland for both soil types. All 1,600 sample points were 
imported into SNAP and used as masks to extract reflectance and classification parameter values for the whole time series. Extracted values were analysed in Microsoft Excel with XLSTAT (Addinsoft, 2015). Sample points affected by cirrus clouds were excluded; this was necessary only for the dataset of 7 June. The distributions of reflectance and parameter values were tested for normality using the Shapiro-Wilk test. Mean parameter values for monoculture and extensive grasslands on peat and clay soils and values for peat vs. clay soils were compared using the Mann-Whitney U non-parametric test. Parameter data for 100 random sample points for each grassland category, in total 400 sample points, were used as training data input for decision tree generation using the demo version of See 5 v2.10 (Rulequest Research, 2017). This demo allows a maximum of 400 sample points as training data. The remaining 1,200 sample points were used as test data to evaluate the See5 classifier.

\section{Classification parameters}

NDVI

The Normalized Difference Vegetation Index (Rouse, 1974) was calculated with the NDVI processor in SNAP 5.0, using bands 4 (QRED) and 8 (QNiR), as advised by ESA in the Sentinel2 technical guide (ESA, 2017c). The NDVI has been used for vegetation monitoring and assessment in countless studies (Frampton et al., 2013). In the current research, change in the NDVI is also used to detect mowing.

\section{S2REP}

The Sentinel-2 Red-edge Position (S2REP) can be used as an indicator for chlorophyll content and may also be a useful indicator of fertilization (Frampton et al., 2013; Sibanda et al., 2015; Sibanda et al., 2017). Since it is based on the red-edge bands, the S2REP may allow discrimination between the different grassland categories. It was calculated using the S2REP processor in SNAP 5.0 according to the formula: $705+35 *\left(\left(\left(\left(\varrho_{\mathrm{B} 7}+\mathrm{B} 4\right) / 2\right)-\varrho_{\mathrm{B} 5}\right) /\left(\varrho_{\mathrm{B} 6}-\right.\right.$ Qв5)).To establish the REP, a linear interpolation procedure is applied between $705 \mathrm{~nm}$ (B5) and $740 \mathrm{~nm}$ (B6), hence the constants 705 and 35 (Cho \& Skidmore, 2006). The S2REP range for vegetated areas lies between 690 and $740 \mathrm{~nm}$ (ESA Step Forum, 2017).

\section{MASD}

The Mean Absolute Spectral Dynamic (MASD) indicates spectral variability for each pixel over two or more observation dates. It represents vegetation dynamics through time and is an indicator for grassland-use intensity (Franke et al., 2012). It should be noted that MASD only describes the magnitude of the spectral response and does not give any information on the spectral shape. The MASD formula used was:

$$
\operatorname{MASD}=\frac{1}{m-1} \sum_{t=1}^{m-1}\left(\frac{1}{n} \sum_{i=b}^{n}\left|\rho_{i}^{t}-\rho_{i}^{t+1}\right|\right)
$$

where $m$ is the number of observation dates, $t$ is the observation date, $n$ is the number of spectral bands, $b$ is the spectral band, and $\varrho$ is the pixel reflectance (Franke et al., 2012). MASD was calculated using Raster Band maths in SNAP 5.0. Images for 12 March and 7 June were excluded because of the presence of clouds. MASD4_spring is based on four 
images for 1 April, 11 April, 21 April and 8 May $(m=4)$, indicating spectral variability before the first mowing date of extensive grasslands. MASD7_total (April-September) also includes 20 July, 8 September and 25 September $(m=7)$. MASD between subsequent observation dates was also calculated. Reflectance for Sentinel-2 bands 2, 3, 4, 5, 6, 7, 8, 8A, 11 and 12 was used for the MASD calculation $(n=10)$.

\section{See5 data-mining software}

See5 data-mining software can be used to reveal data patterns that allow classification into categories using the C5.0 univariate decision tree (DT) machine learning algorithm (Quinlan, 2014; Rulequest Research, 2017). DTs are computationally fast and analysts can easily interpret their outcomes; furthermore, they do not require statistically normal distributed data (Pal \& Mather, 2003). The measure used to partition data into different classes is the normalized information gain (difference in entropy) (Santini, 2015). At each node of the DT, the algorithm aims to decrease the dataset's entropy by creating more homogeneous subsets (Santini, 2015). The procedure is recursively repeated, creating new branches on the tree, until all data is classified. If the training data contains noise, overfitting may occur. To avoid this, DTs may be pruned, reducing the number of branches (Pal \& Mather, 2003; Kotsiantis, 2007). See 5 was selected because Franke et al. (2012) achieved good results using this method. Moreover, since values for reflectance, NDVI and S2REP were not normally distributed, maximum likelihood classification could not be used. The demo version of See5 v2.10 was used to establish NDVI, S2REP and MASD thresholds that allow the classification of monoculture and extensive grasslands on clay and peat soils. The DT created was used to derive decision rules. These rulesets were implemented in QGIS to create the final maps using the 'import rules from text file' function in the band calculations menu of the Semi-Automatic Classification Plugin v5.2.4 (Congedo, 2016). See5 also shows which attributes dominate the classification. The importance of specific attributes for classification was tested by removing values for 21 April and repeating the See5 analysis. Two related classifications were evaluated:

1) Statistical rule-based classification

This method uses See 5 statistical analysis of parameter values for 26 attributes: NDVI and S2REP values for all nine observation dates, MASD4_spring, MASD7_total, and the MASD between seven observation dates.

\section{2) Contextual rule-based classification}

This classification applies contextual knowledge of seasonal aspects of agricultural grassland management practices (Franke et al., 2012). Specifically, knowledge of first mowing dates is used to avoid misclassification of monoculture fields that are mown before 21 April. It also aims to test whether good classification results can be achieved by implementing simplified decision rules when the classifier is based only on three attributes: S2REP, NDVI for 21 April, and MASD4_spring values. Mowing causes a strong, sudden decrease in biomass and crop height and reduces NDVI values (Courault et al., 2010; Dussaux et al., 2014; Lips, 2011). Under the right weather conditions, vegetation recovers within ca. 15 days (Courault et al., 2010). If the gap between two observation dates is longer than 10-15 days, mowing may not be detected. Based on change in NDVI between 21 April and 8 May, a mowing threshold of -0.1 was established and added to the decision rules for mapping in QGIS. 


\section{Results and discussion}

\section{Spectral separability}

In springtime, for all spectral bands on both clay and peat soils, the Mann Whitney $U$ test showed that mean spectral response for extensive grasslands differs significantly from monoculture grasslands ( $p<0.0001$, alpha 0.05 for 21 April) (Figure 5). After the first mowing event, spectral response patterns show more overlap; differences between monoculture and extensive grassland are no longer significant for several spectral bands. Local soil type strongly influences spectral response. When comparing clay vs. peat soils, mean reflectance values for extensive grassland and monoculture grasslands are significantly different in spring ( $\mathrm{p}<0.0001$, alpha 0.05 for 21 April). In a study area with mixed soils, training data for both soil types is required to avoid misclassification. Coincident spectral plots were created to assess whether the range of values shows overlap. After the first mowing date, boxes show strong overlap.
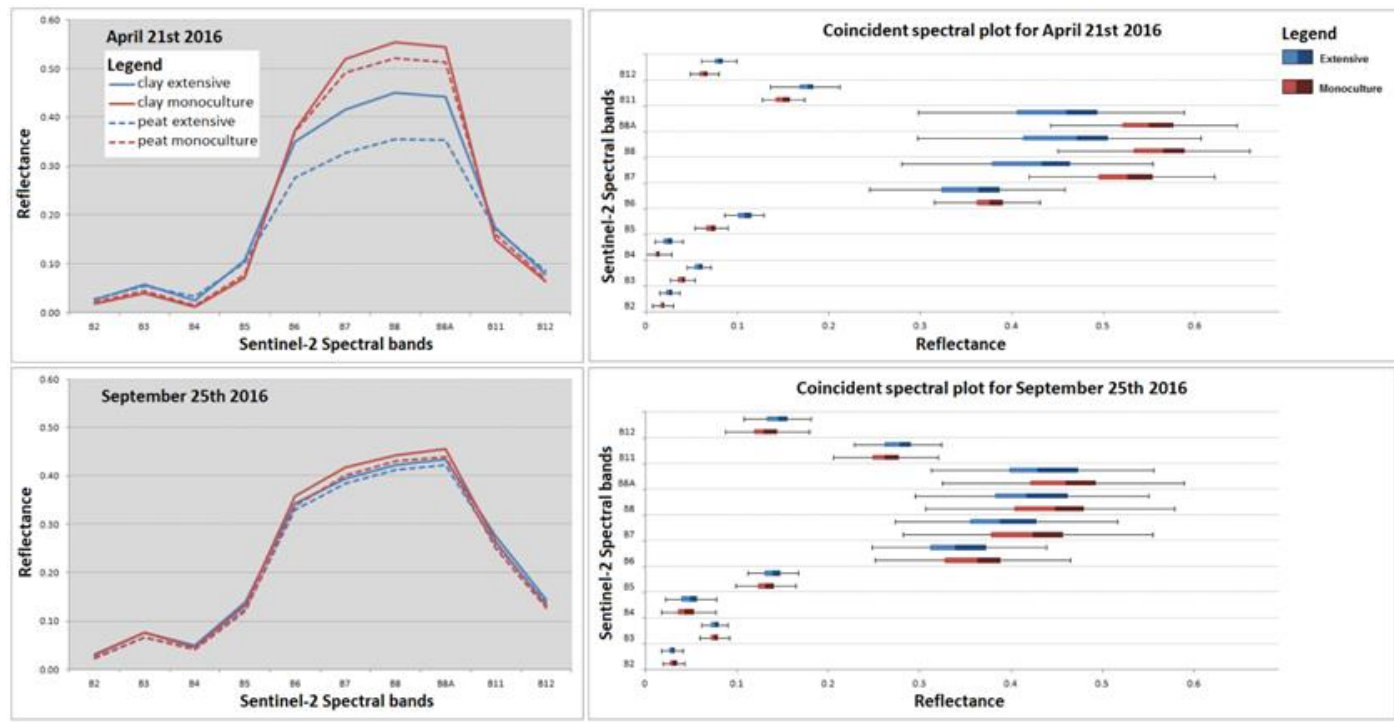

Figure 5: Spectral reflectance curves for 21 April and 25 September, based on mean reflectance values for extensive and monoculture grassland on clay and peat soils, and coincident spectral plots for clay soils

\section{Vegetation Index time series analysis}

Seasonal grass production curves typically display two peaks. Grass growth starts in March, speeds up in April and reaches its highest peak in May. In June and July, growth slows down due to slower re-growth after the first cut, but this is also related to the flowering season for grass vegetation. The second peak is reached in August/September (Visscher, 2010). The seasonal pattern of the S2REP and NDVI time series is comparable to the grassland 
production curve, showing a peak in May, lower values in July, and a second peak in September (Figure 6).

The NDVI time series for extensive grasslands on peat soils shows a delayed onset of grass growth, with a peak in June, whilst monoculture grasslands reach their peak on 21 April. Delayed onset of grass growth on peat is caused by lower soil temperatures due to high groundwater levels in spring (Gollenbeek \& Hoving, 2016). Moreover, due to wet soil conditions, manuring cannot start as early as on clay soils.

In spring, NDVI for monoculture grassland displays a narrow range compared to extensive grassland, reflecting the homogeneous character of ryegrass monocultures in contrast to the heterogeneous extensive grasslands that include various types of grasses and herbs. From May onwards, monoculture grassland on clay soils shows more variation in NDVI due to mowing; first cuts were taken between 6 and 12 May. For monoculture on peat, NDVI variation increases in June; first cuts were taken between 8 May and 7 June. In July, NDVI of extensive grassland drops strongly for both clay and peat soils, since after 15 June mowing is allowed in bird reserves. The NDVI drop in July may also be related to slower grass growth during the flowering season.

The S2REP time series follows a similar pattern, but compared to the NDVI time series, less overlap occurs between extensive and monoculture grasslands. For monoculture on clay soils, the highest mean value is $727 \mathrm{~nm}$, compared to $726 \mathrm{~nm}$ for peat soils; $722 \mathrm{~nm}$ for extensive grassland on clay soils, and $723 \mathrm{~nm}$ for peat soils. The S2REP for extensive grasslands on clay and peat soils shows significant overlap, although the S2REP range is wider for peat soils. High S2REP values for monoculture grasslands are probably related to high amounts of chlorophyll and nitrogen in the leaves, stimulated by the application of liquid manure.

\section{Classification}

After See 5 analysis of 26 attributes, the DT for statistical classification uses only five attributes for four observation dates (Table 2). S2REP values for 21 April are the most important for classification (100\% attribute usage), followed by S2REP values for 8 September (51\%), and NDVI values for 21 April (50\%). See5 evaluation on test data (= the sample points not used for training) reveals an error of $4.6 \%$. The higher error percentage in test data compared to training data may be due to overfitting to noise in the training data (Pal \& Mather, 2003). Despite careful selection of sample areas, it is still possible that some training samples may have been allocated to the wrong class. After See5 analysis of three attributes, the DT for contextual classification uses two attributes. Again, S2REP for 21 April is the most important attribute used for classification (100\%), followed by NDVI for 21 April (50\%), whilst MASD4_spring is not used (Table 2). The accuracy for the test data is similar to that of the statistical classification. 

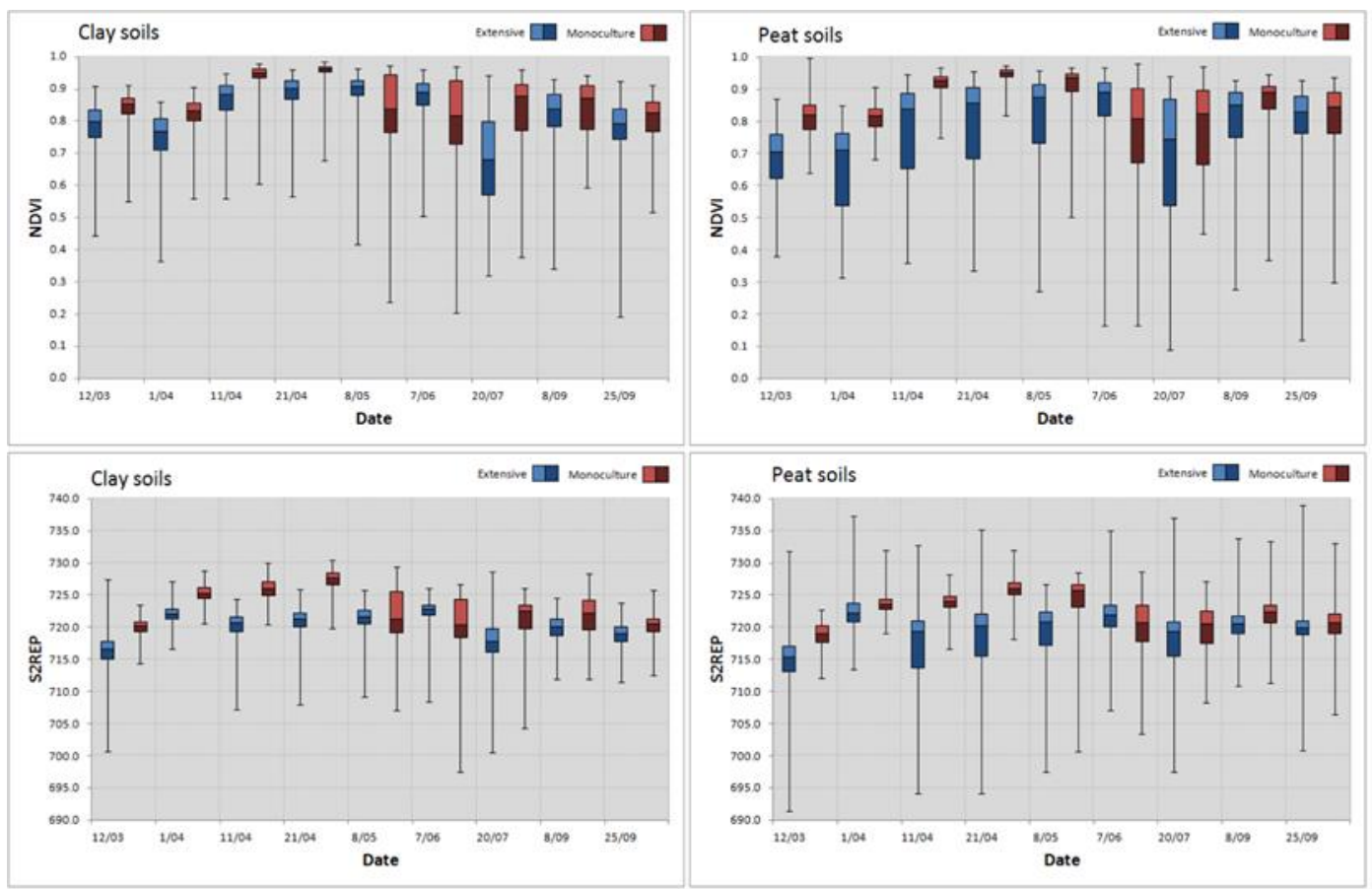

Figure 6: NDVI and S2REP boxplot time series for extensive and monoculture grassland on clay and peat soils.

The S2REP and NDVI for 21 April are dominant attributes that allow fast splitting into either monoculture or extensive grassland. See5 analysis was repeated without S2REP and NDVI for 21 April to test the importance of other attributes. If the dominant attributes are discarded, See 5 needs to consider more attributes to achieve the final classification and returns a more complex DT in which S2REP for 11 April is the most important attribute $(100 \%)$, followed by MASD4_spring (55\%) (which still includes 21 April), S2REP for 8 May $(45 \%)$, and S2REP for 12 March (42\%). This illustrates the importance of the S2REP for classification and confirms that April is the optimal month to discriminate between extensive and monoculture grassland. Since spring temperatures throughout the Netherlands show little variation, this will hold true for the whole country. This is consistent with the findings of Nitze, Barret \& Cawkwell (2015), who used DTs for grassland classification in Ireland. When comparing classification results with the ground truth map, overall accuracy (Congalton, 1991) for the contextual classification is slightly higher (84.3\%) than for the statistical classification (82.5\%). Cohen's kappa coefficient (KHAT) (Cohen, 1960) is also higher for the contextual classification: 0.65 (= substantial agreement) compared to 0.59 (= moderate agreement). This is comparable to the results of Franke et al. (2012). Lower overall accuracy for the statistical classification is mainly due to misclassification of monoculture fields that were mown before 21 April. If the mowing threshold is added to the statistical classification, its overall accuracy increases to $83.3 \%$ with a KHAT of 0.60 . Monoculture grasslands may also be misclassified as extensive grasslands due to recent reseeding, slower grass growth in fields that have been used for maize crops in previous years, 
fields that are intensively grazed, and failure to detect mowing if gaps in the time series are too wide. Contrary to the findings of Franke et al. (2012), the MASD attributes did not contribute much to the classifications. The reason for this is probably that the 21 April image is dominant, since spectral separability was extremely good on this date. If no such dominant image is available, MASD may be more useful. But, in all cases, the S2REP outperformed the MASD. Provided that adequate springtime imagery is available, accurate grassland management classification does not necessarily require data for many observation dates. The statistical method uses four scenes and the contextual method two. The contextual classification requires data from two consecutive observation dates, preferably at an interval of 10-15 days, to be able to detect mowing of intensively managed grasslands. Mowing can be detected at parcel level (Appendix A).

Table 2: Attribute usage and comparison of classification accuracy for statistical and contextual classification

\begin{tabular}{|l|l|l|}
\cline { 2 - 3 } \multicolumn{1}{c|}{} & Statistical classification & $\begin{array}{l}\text { Contextual } \\
\text { classification }\end{array}$ \\
\hline $\begin{array}{l}\text { Total nr. of attributes used as } \\
\text { input in See5 }\end{array}$ & 26 & 3 \\
\hline Final attribute usage (See5) & $\begin{array}{l}100 \% \text { S2REP21April } \\
51 \% \text { S2REP8Sep } \\
50 \% \text { NDVI21April } \\
7 \% \text { S2REP25Sep } \\
4 \% \text { MASD21Apr8May }\end{array}$ & $\begin{array}{l}100 \% \text { S2REP21April } \\
50 \% \text { NDVI21April } \\
0 \% \text { MASD4Spring }\end{array}$ \\
\hline $\begin{array}{l}\text { Accuracy on training data } \\
\text { (See5) } \\
\text { (400 sample points) }\end{array}$ & $99.2 \%$ & $96.7 \%$ \\
\hline $\begin{array}{l}\text { Accuracy on test data (See5) } \\
\text { (1200 sample points) }\end{array}$ & $95.4 \%$ & $95.4 \%$ \\
\hline $\begin{array}{l}\text { Overall accuracy (final map) } \\
\text { compared to ground truth } \\
\text { vector map }\end{array}$ & $82.5 \%$ & $84.3 \%$ \\
\hline KHAT (final map) & 0.59 & 0.65 \\
\hline Nr. of scenes used (final map) & 4 & 2 \\
\hline
\end{tabular}

\section{Contextual classification for South-Central Friesland study area}

The contextual classification was applied to the whole study area and validated through an overlay of (meadow) bird areas that are part of the National Nature Network, as well as of locations of organic/bird-friendly farmers, because here one expects to find extensive grassland (Figure 7). 40.3\% of the grassland is classified as extensive and $59.7 \%$ as monoculture. Indeed, nearly all grassland in nature areas is classified as extensive; concentrations of extensive grassland are also found near organic/bird-friendly farms. Peat soils contain relatively more extensive grassland than clay soils. The reason for this may be that these soils are less suitable for intensive management due to higher groundwater levels. 


\section{Bekkema \& Eleveld}

The classification method could probably be successfully applied for other grassland areas in the Netherlands, because most meadow bird grasslands lie on clay or peat soils. However, no thorough accuracy assessment was performed for the peat soil area due to lack of time. Therefore, further validation of the model is required.

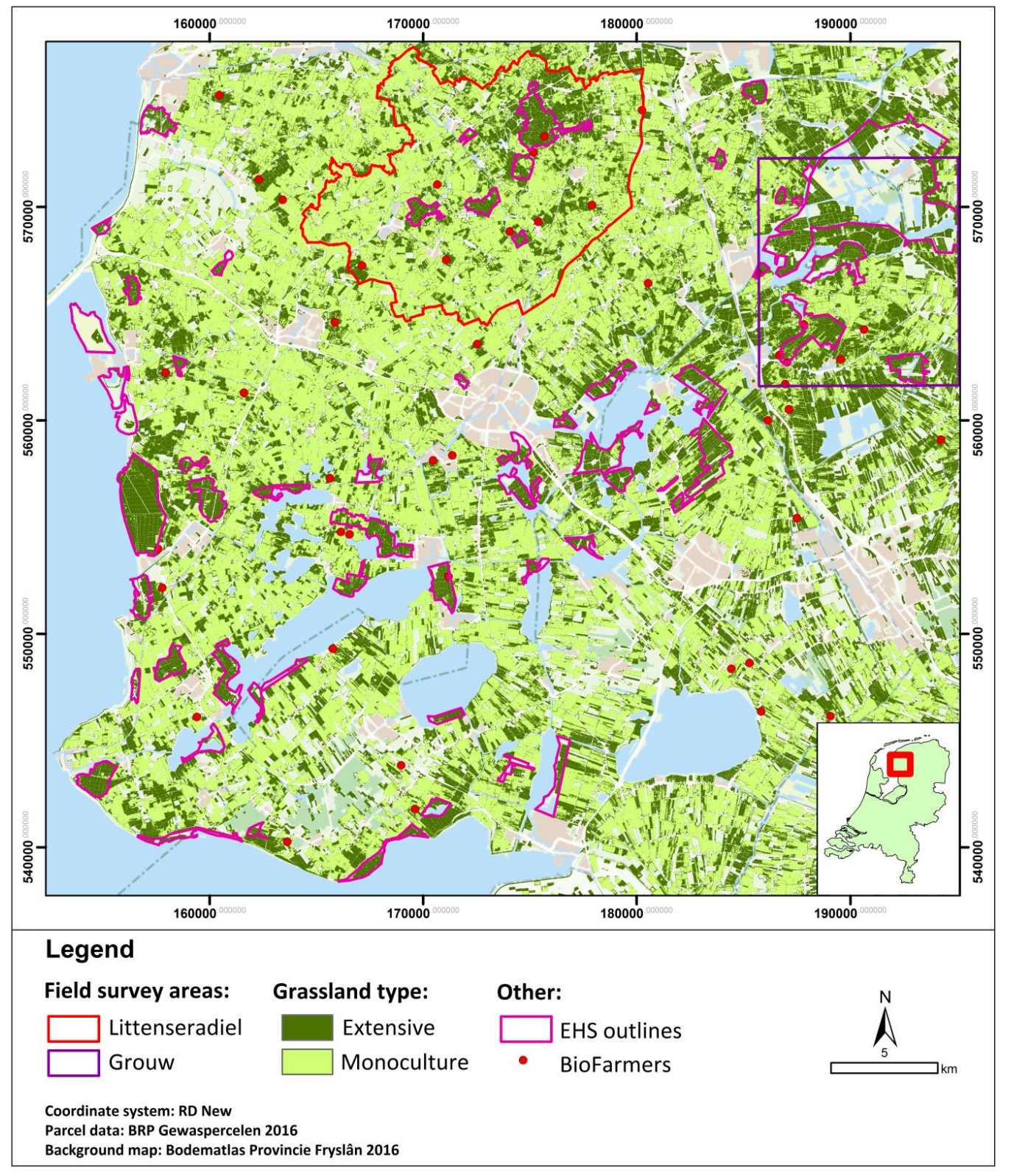

Figure 7: Grassland classification for study area compared to National Nature Network (EHS) and organic/bird-friendly farms 


\section{Grassland management compared to distribution of godwit nests}

To illustrate its potential use for meadow bird conservation, the contextual classification map was compared to the distribution of registered nests of lapwing, redshank, godwit and oystercatcher in Littenseradiel (Figure 8 \& Appendix B). All species, especially godwit and redshank, prefer extensive grassland as nesting sites (Table 3). Lapwings also favour bare lands/croplands over monoculture grassland. Nevertheless, $20 \%$ of the combined species breed on monoculture grasslands. Here, protection of nests and chicks remains essential.

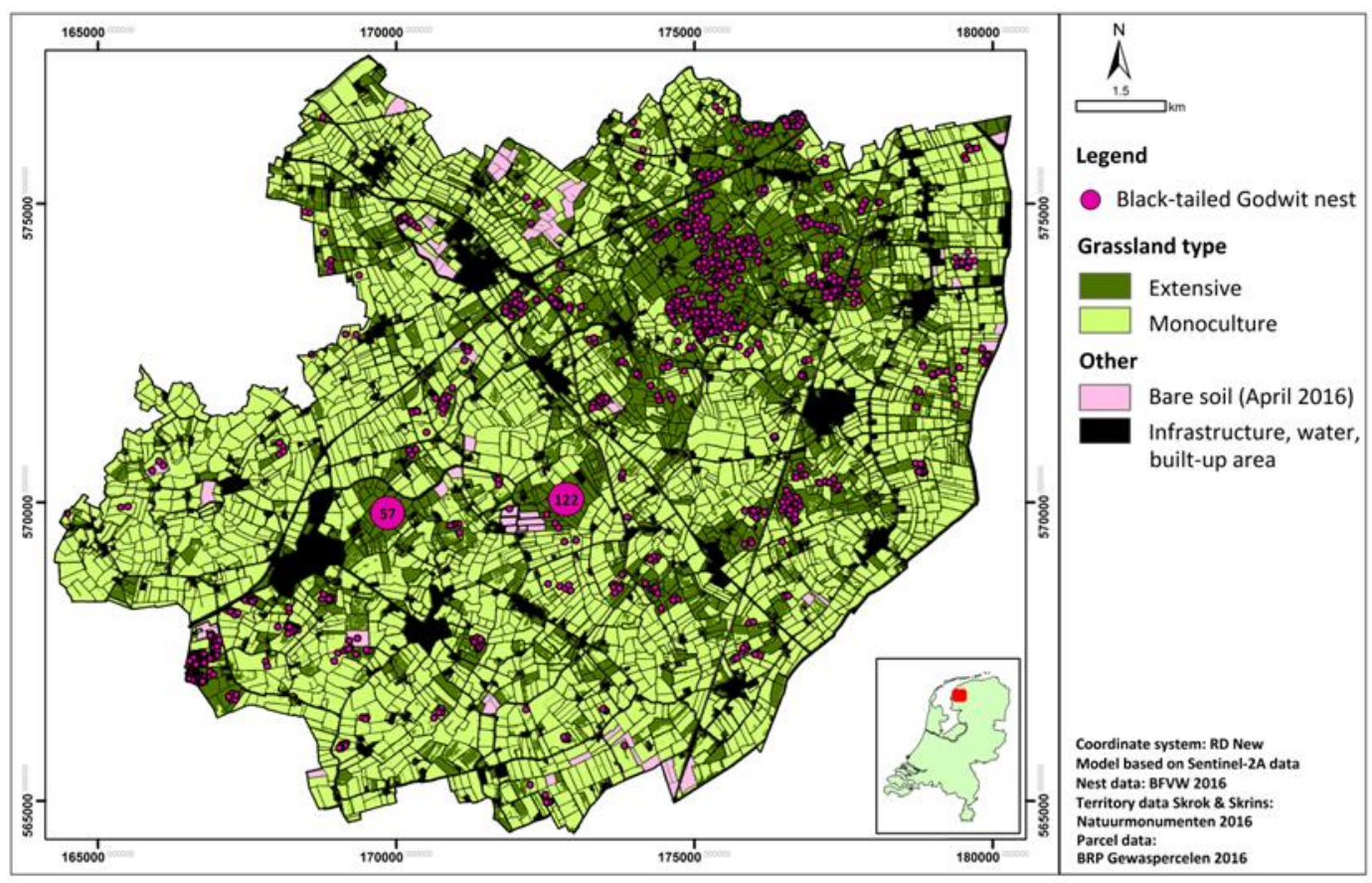

Figure 8: Contextual classification compared to distribution of registered Black-tailed Godwit nest sites for Littenseradiel 2016. Total numbers are given for Skrok and Skrins meadow bird reserves (nest distribution data from Bond Friese Vogel Wachten, 2016; nr. of territories for Skrok and Skrins from De Boer \& De Winter, 2016) 
Table 3: Grassland type compared to distribution of nests in Littenseradiel (2016) for four meadow bird species

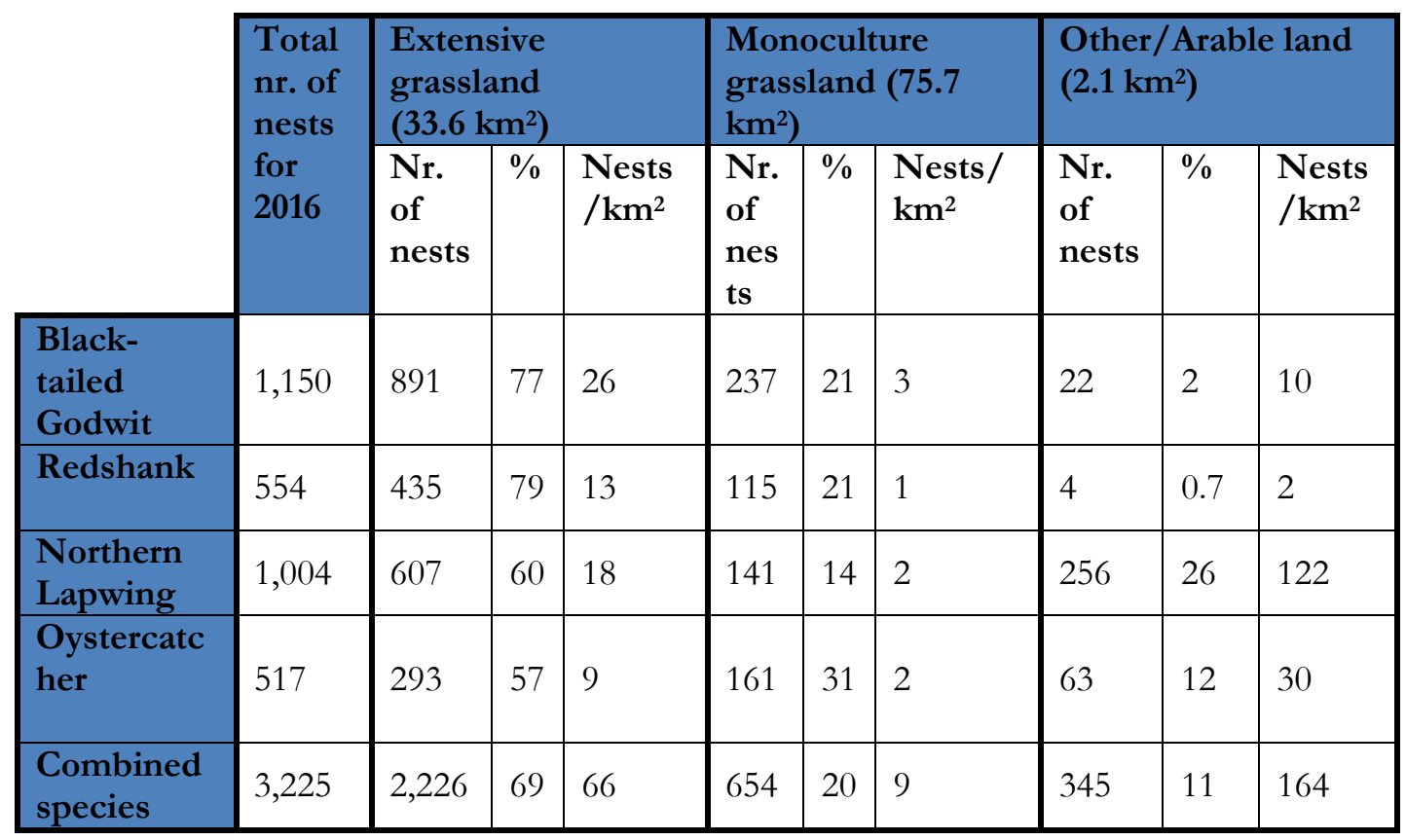

\section{Conclusion}

Sentinel-2 has great potential for detecting grassland management intensity at parcel level. The S2REP vegetation index in particular is an important classification parameter, serving as an indicator of fertilization. Availability of springtime imagery, preferably acquired in the second half of April, before the first mowing date, is essential for accurate classification. The current method incorporates expert knowledge on local management, specifically with regard to mowing. If the method is to be used in a (semi)-automated operational process and applied in study areas for which no knowledge of mowing is available, it is essential to have a reliable mowing model. With the additional availability of Sentinel-2B data, temporal resolution is increased to five days, increasing the chance of acquisition of cloud-free images. Detection of mowing may be improved by using Sentinel-1 Synthetic Aperture Radar data (Howison et al., 2018; Tamm, Zalite, Voormansik \& Talgre, 2016). Local soil type strongly influences the spectral response of grassland. In a study area with mixed soils, training data for all soil types is required to avoid misclassification. The validity of the model needs further testing, since classification thresholds may vary from year to year, depending on weather conditions in spring. Similarly, it might be worthwhile to test the method in other regions. In general, we conclude that freely available remote sensing data and techniques can be used to monitor agri-environmental measures at local, parcel and landscape scale, which can hopefully contribute to the conservation of grassland biodiversity. 


\section{Acknowledgements}

We are grateful to Marco Hoekstra of the Bond Friese Vogelwachten, who kindly provided GIS data of nesting sites for meadow birds in Littenseradiel. Thanks are also due to Jelle de Boer and Simon de Winter of Natuurmonumenten for providing meadow bird data for Skrins and Skrok. This paper contains modified Copernicus Sentinel data. Finally, thanks to UNIGIS Amsterdam coordinator Niels van Manen, to Prof. Henk Scholten, as well as to Prof. Jan-Peter Mund for comments during the MSc research.

\section{References}

Addinsoft (2015). XLSTAT Software. Retrieved from https://www.xlstat.com/en/

Ali, I., Cawkwell, F., Dwyer, E., Barrett, B. \& Green, S. (2016). Satellite remote sensing of grasslands: from observation to management. Journal of Plant Ecology, 9(6), 649-671. DOI:10.1093/jpe/rtw005

Asam, S., Klein, D. \& Dech, S. (2015, May). Estimation of grassland use intensities based on high

spatial resolution LAI time series. The International Archives of the Photogrammetry, Remote

Sensing and Spatial Information Sciences, Volume XL-7/W3, 36th International Symposium on

Remote Sensing of Environment, Berlin, Germany

Bekkema, M.E. (2017). The potential of Sentinel-2 data for detecting grassland management intensity to support monitoring of meadow bird populations. Master thesis, UNIGIS, VU Amsterdam

BFVW (2017). Bond Friese VogelW achten. Retrieved from

http://www.friesevogelwachten.nl/nl/home.html

Boer, J. de \& de Winter, S. (2016). Greidhoeke en Lytse Bouboeke. Vogelinventarisatie 2016. Natuurmonumenten rapport

Cho, M.A. \& Skidmore, A.K. (2006). A new technique for extracting the red edge position from hyperspectral data: The linear extrapolation method. Remote Sensing of Environment, 101, 181-193. DOI:10.1016/j.rse.2005.12.011

Clevers, J.G.P.W. \& Gitelson, A.A. (2013). Remote estimation of crop and grass chlorophyll and nitrogen content using red-edge bands on Sentinel-2 and -3. International Journal of Applied Earth Observation and Geoinformation, 23, 344-351. DOI:10.1016/j.jag.2012.10.008

Cohen, J. (1960). A coefficient of agreement for nominal scales. Educational and Psychological Measurement, 20, 37-46

Congalton, R.G. (1991). A Review of Assessing the Accuracy of Classifications of Remotely Sensed Data. Remote Sensing of Environment, 37, 35-46. DOI:10.1016/0034-4257(91)90048-B

Congedo Luca (2016). Semi-Automatic Classification Plugin Documentation. Retrieved from DOI:10.13140/RG.2.2.29474.02242/1

Courault, D., Hadria, R., Ruget, F., Olioso, A., Duchemin, B., Hagolle, O. \& Dedieu, G. (2010). Combined use of FORMOSAT-2 images with a crop model for biomass and water monitoring of permanent grassland in Mediterranean region. Hydrology and Earth System Sciences, 14, 1731-1744. DOI:10.5194/hess-14-1731-2010

Delegido, J., Verrelst, J., Meza, C.M., Rivera, J.P., Alonso, L. \& Moreno, J. (2013). A red-edge spectral index for remote sensing estimation of green LAI over agroecosystems. European Journal of Agronomy, 46, 42-52. DOI:10.1016/j.eja.2012.12.001

Dussaux, P., Vertès, F., Corpetti, T., Corgne, S. \& Hubert-Moy, L. (2014). Agricultural practices in grasslands detected by spatial remote sensing. Environmental Monitoring and Assessment, 186(12), 8249-8265. DOI:10.1007/s10661-014-4001-5 
ESA (2017a). Copernicus website. Overview. Retrieved from http://www.esa.int/Our_Activities/Observing_the_Earth/Copernicus/Overview ESA (2017b).

Sentinels Scientific Data Hub. Retrieved from https://scihub.copernicus.eu/

ESA (2017c). Sentinel-2 Technical Guide. Level-2A Algorithm Overview. Retrieved from https://sentinel.esa.int/web/sentinel/technical-guides/sentinel-2-msi/level-2a/algorithm

ESA Step Forum (2017). S2REP output flag 4. Retrieved from http:// forum.step.esa.int/t/s2repoutput-flag-4/4455

Frampton, W.J., Dash, J., Watmough, G. \& Milton, E.J. (2013). Evaluating the capabilities of Sentinel2 for quantitative estimation of biophysical variables in vegetation. ISPRS Journal of Photogrammetryand Remote Sensing, 82, 83-92. DOI:10.1016/j.isprsjprs.2013.04.007

Franke, J., Keuck, V. \& Siegert, F. (2012). Assessment of grassland use intensity by remote sensing to support conservation schemes. Journal for Nature Conservation, 20, 125-134 DOI:10.1016/j.jnc.2012.02.001

Gitelson, A.A., Viña, A., Verma, S., Rundquist, D.C., Arkebauer, D.C., Keydan, T.J., Galina, P., Leavitt, B., Ciganda, V., Burba, G.G. \& Suyker, A.E. (2006). Relationship between gross primary production and chlorophyll content in crops: Implication for the synoptic monitoring of vegetation productivity. Journal of Geophysical Research, 111, 13p. DOI:10.1029/2005JD006017

Gollenbeek, L. \& Hoving, I. (2016). Voorjaarsbemestingsadvies grasland op basis van bodemtemperatuur. Rapport 1004. Wageningen Livestock Research Wageningen

Groen, N.M., Kentie, R., Goeij, P. de, Verheijen, B., Piersma, T. \& Hooijmeijer, J. (2012). A modern landscape ecology of Black-tailed Godwits: Habitat selection in southwest Friesland, The Netherlands. Ardea, 100(1), 19-28. DOI:10.5253/078.100.0105

Halabuk, A., Mojses, M., Halabuk, M. \& David, S. (2015). Towards Detection of Cutting in Hay Meadows by Using of NDVI and EVI Time Series. Remote Sensing, 7, 6107-6132 DOI:10.3390/rs70506107

Howison, R.A., Piersma, T., Kentie, R., Hooijmeijer, J.C.E.W. \& Olff, H. (2018). Quantifying landscape- level land-use intensity patterns through radar-based remote sensing. Journal of Applied Ecology, 2018, 1-12. DOI:10.1111/1365-2664

Kentie, R., Hooijmeijer, J.C.E.W., Trimbos, K.B., Groen, N.M. \& Piersma, T. (2013). Intensified agricultural use of grasslands reduces growth and survival of precocial shorebird chicks. Journal of Applied Ecology, 50, 243-251. DOI:10.1111/1365-2664.12028

Kotsiantis (2007). Supervised Machine Learning: A Review of Classification Techniques. Informatica, 31, 249-268. Retrieved from http://www.informatica.si/index.php/informatica/article/view/148.

Lips, M. (2011). Detection of grassland management intensity using MODIS satellite imagery. Centre for GeoInformation. Thesis Report GIRS-2011-21. Wageningen University and Research Centre

Mueller-Wilm, U. (2016). ESA Sentinel-2. Sen2Cor Configuration and User Manual. S2-PDGS-MPC-L2ASUM-V2.3, Issue 1, Date 2016-11-25

Nationaal georegister (2017). Basisregistratie gewaspercelen 2016. Retrieved from http:/ /www.nationaalgeoregister.nl/

Nitze, I., Barret, B. \& Cawkwell, F. (2015). Temporal Optimisation of image acquisition for land cover classification with Random Forest and MODIS time series. International Journal of Applied Earth Observation and Geoinformation, 34, 136-146. DOI:10.1016/j.jag.2014.08.001

Pal, M. \& Mather, P.M. (2003). An assessment of the effectiveness of decision tree methods for land cover classification. Remote Sensing of Environment, 86, 554-565 DOI:10.1016/S0034-4257(03)001329 Provincie Fryslân (2017). Natuurbeheerplan 2017. Retrieved from http://www.fryslan.frl/beleidsthemas/natuurbeheerplan-2017_3541/

Quinlan, J.R. (2014). C4.5: Programs for Machine Learning. Elsevier

Ramoelo, A., Cho, M., Mathieu, R. \& Skidmore, A.K. (2015). Potential of Sentinel-2 spectral configuration to assess rangeland quality. Journal of applied remote sensing, 9, $12 \mathrm{p}$.

DOI:10.1117/1.JRS.9.094096 
Rouse Jr., J.W., Haas, R.H., Schell, J.A. \& Deering, D.W. (1974). Monitoring Vegetation Systems in the Great Plains with ERTS. Third Earth Resources Technology Satellite-1 Symposium. Paper A20, 309-317

Rulequest Research (2017). See5 Data Mining Software. Retrieved from https://www.rulequest.com/see5-info.html

Santini, M. (2015). Machine learning for language technology 2015. Decision Trees. Lecture slides. Retrieved from https://www.slideshare.net/marinasantini1/lecture-4-decision-trees-2-entropy-informationgain-gain-ratio- 55241087

Schuster, C., Förster, M. \& Kleinschmit, B. (2012). Testing the red-edge channel for improving landuse classifications based on high-resolution multi-spectral satellite data. International Journal of Remote Sensing, 33(17), 5583-5599. DOI:10.1080/01431161.2012.666812

Sibanda, M., Mutanga, O. \& Rouget, M. (2015). Examining the potential of Sentinel-2 MSI spectral resolution in quantifying above ground biomass across different fertilizer treatments. ISPRS Journal of Photogrammetry and Remote Sensing, 110, 55-65. DOI:10.1016/j.isprsjprs.2015.10.005

Sibanda, M., Mutanga, O. \& Rouget, M. (2017). Testing the capabilities of the new WorldView-3 space-borne sensor's red-edge spectral band in discriminating and mapping complex grassland management treatments. International Journal of Remote Sensing, 38(1), 1-22 DOI:10.1080/01431161.2016.1259678

Tamm, T., Zalite, K., Voormansik, K. \& Talgre, L. (2016). Relating Sentinel-1 Interferometric Coherence to Mowing Events on Grasslands. Remote Sensing, 8(10), 1-19.

DOI:10.3390/rs8100802USGS (2017). USGS Spectral Characteristics Viewer. Retrieved from https://landsat.usgs.gov/spectral-characteristics-viewer

Visscher, J. (2010). Verlenging groeiseizoen grasland. Rapport 301, Lelystad: Wageningen UR Livestock Research 
Bekkema \& Eleveld

Appendix A: Mowing map for Littenseradiel

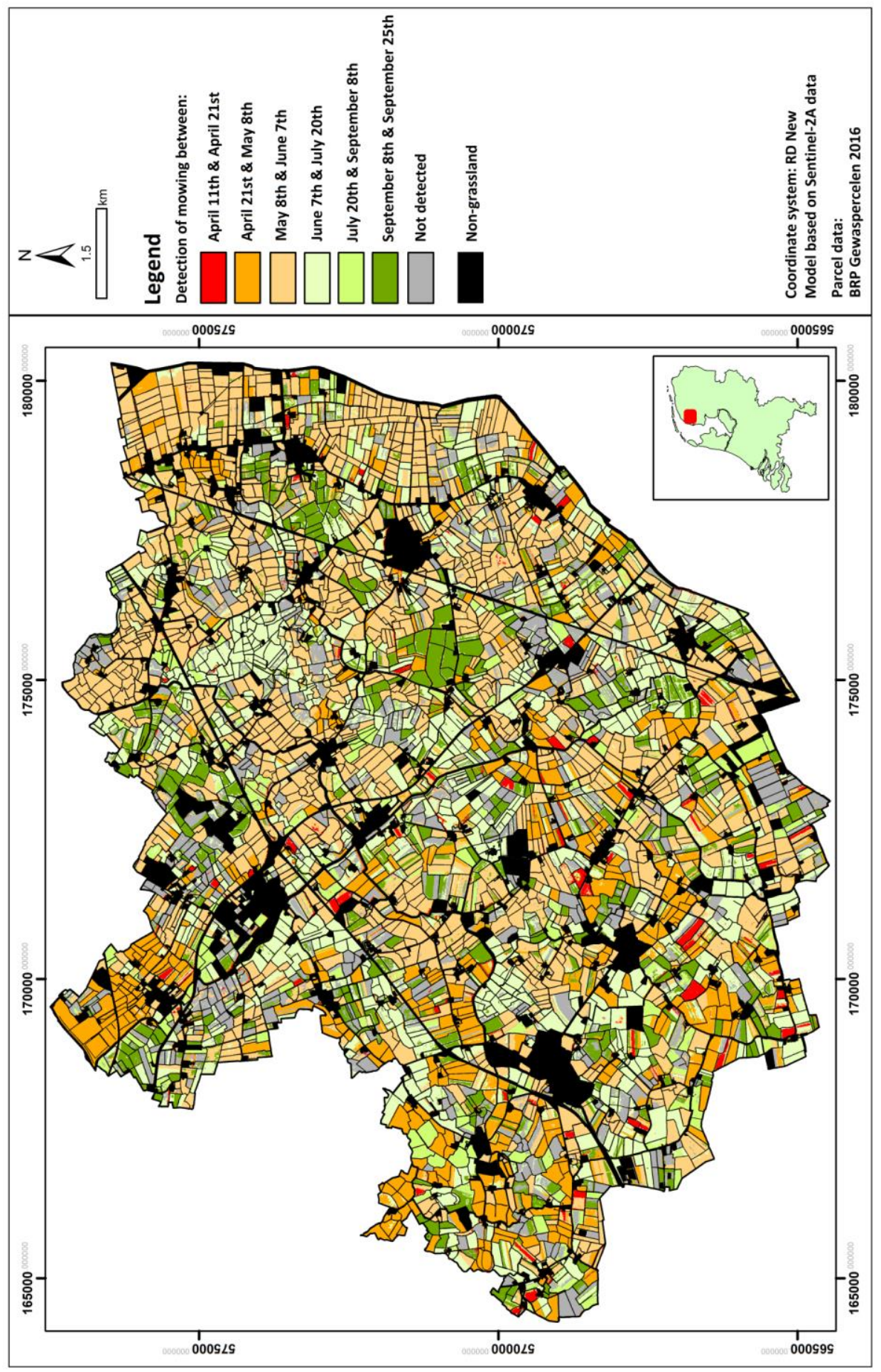


Appendix B:

Distribution of 2016 meadow-bird territories/nests compared to grassland management

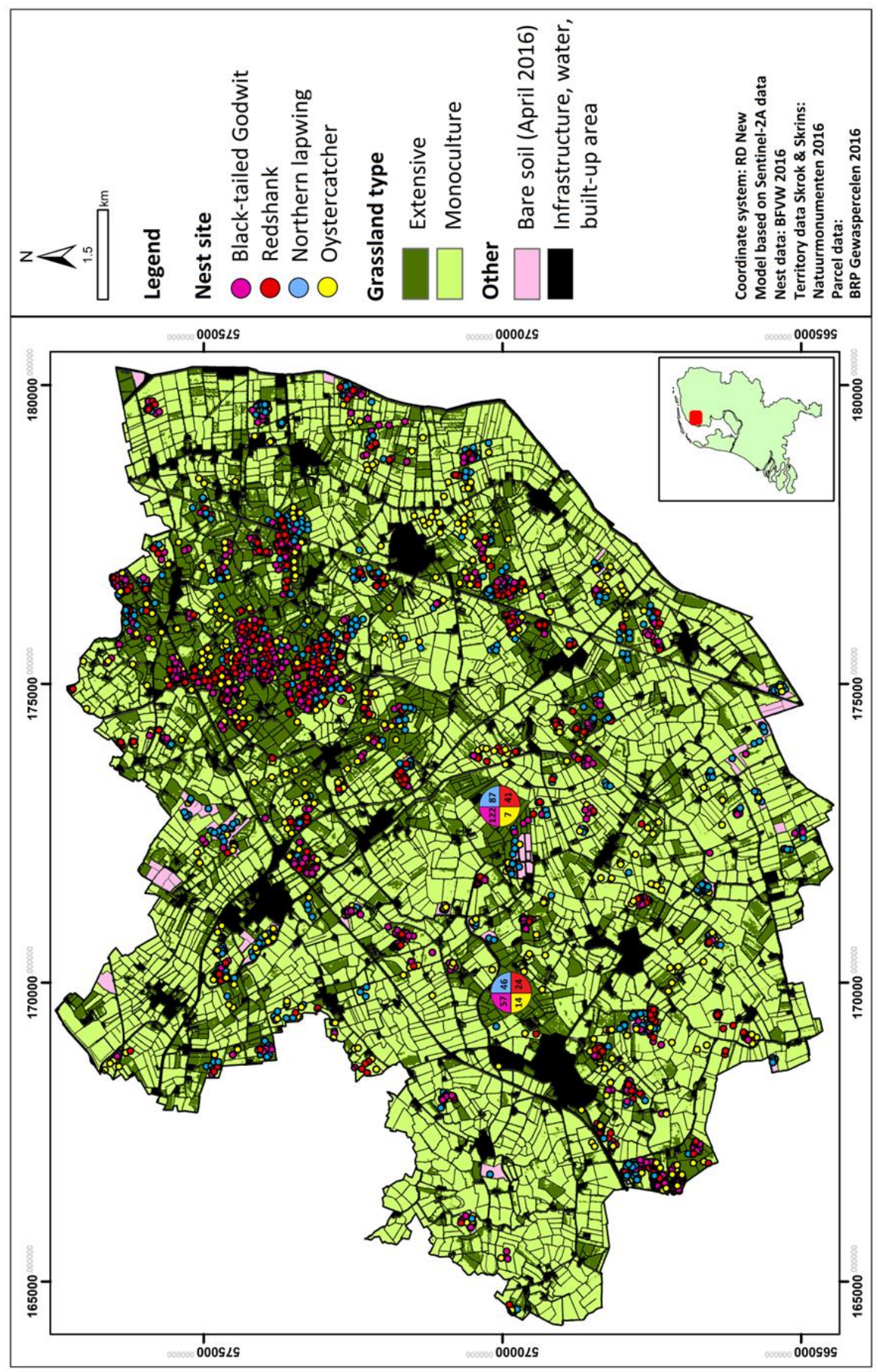

